抄 銭

\title{
惡性腫演とカルシウム代謝・特に癌の發生と カルシウム代謝に就て
}

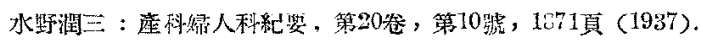

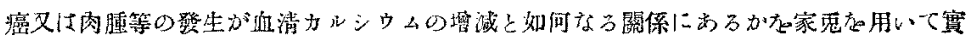

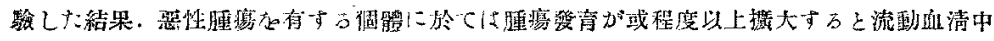

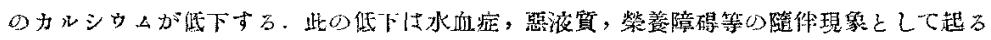

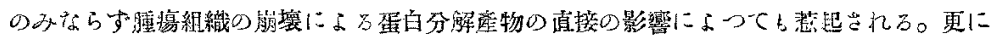

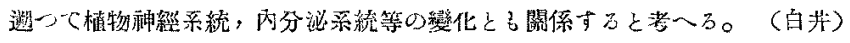

\section{鉛コロイドの惡性腫瘍發㕕に及ぼす影響}

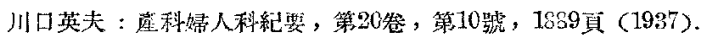

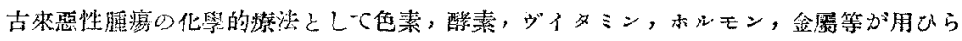

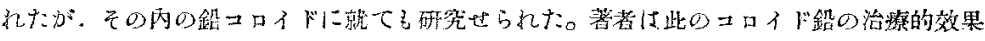

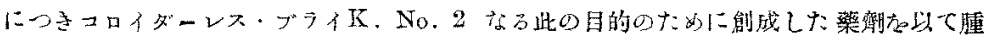

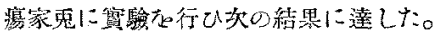

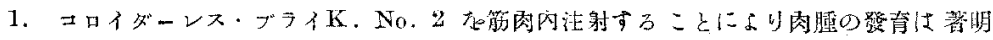

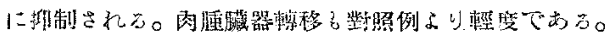

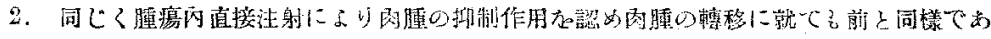
3o

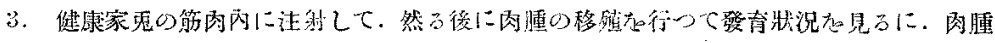

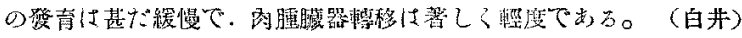

\section{惡性腫㾤の造血臓器に及ぼす影響}

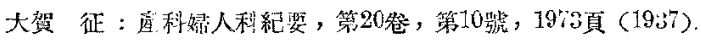

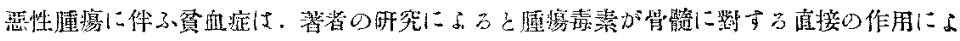

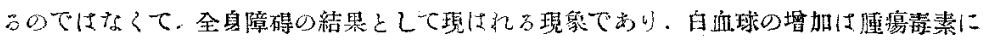

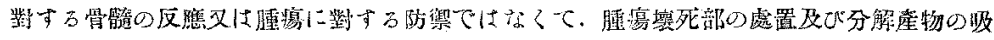

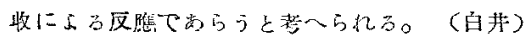

\section{低溫作用動物に對する被覆物の影響 \\ 附。氣流の影響}




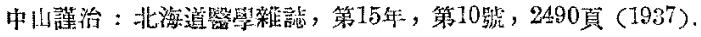

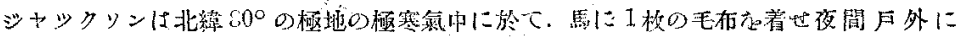

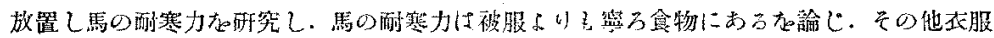

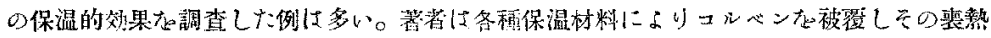

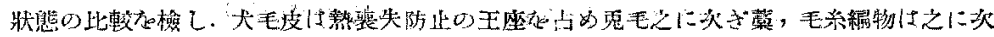

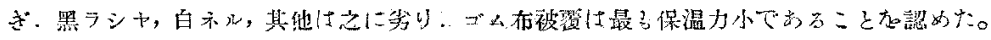

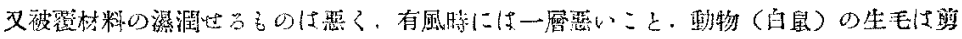

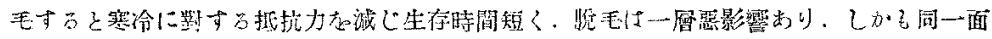

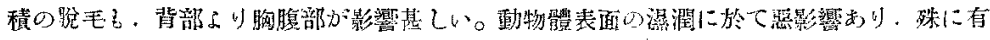
風時一曆大である。

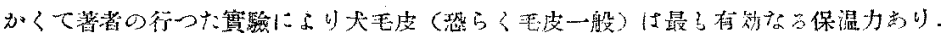

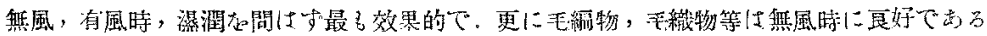

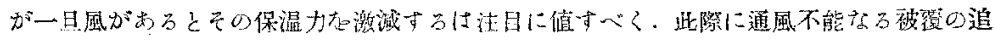

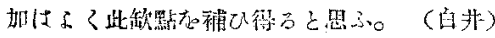

\section{蔬荣類のVITAMIN=C念量の季節的變動に就て}

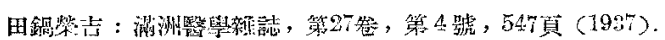

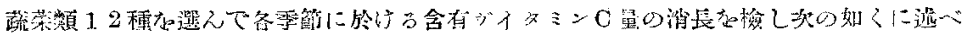

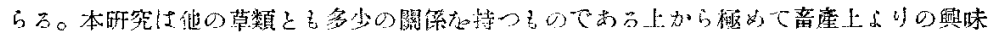
る深いものである。

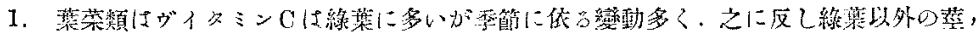

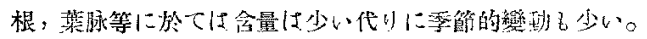

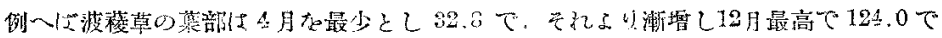

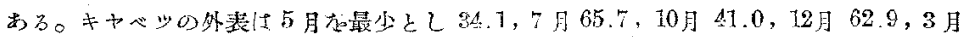

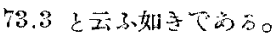

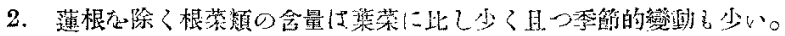

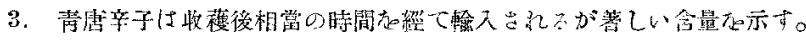

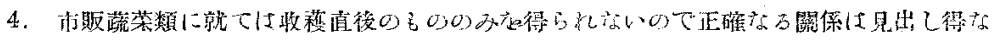
いが大體に於七夏・秋の倾に多い。(的井)

\section{大豆油渒の乳牛飼料しして泌乳量に及ぼす影響}

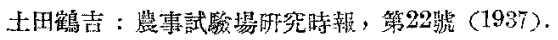

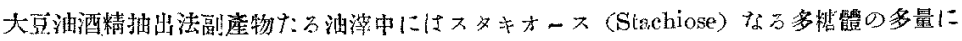

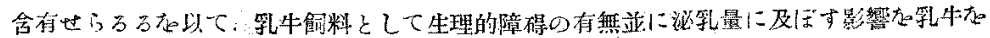

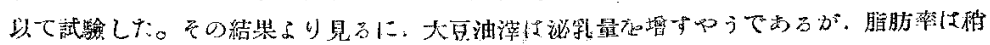




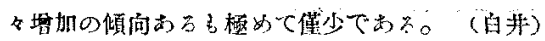

\section{熹糖投與家冤の俧器變化に關する凟驗的研究}

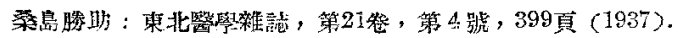

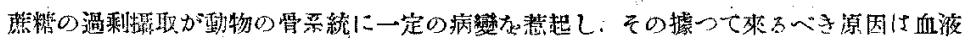

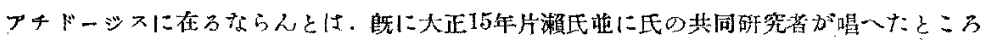

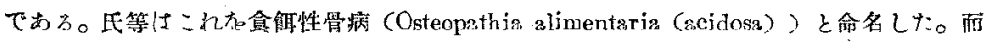

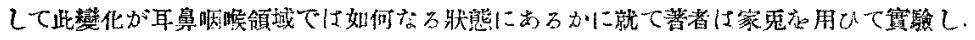

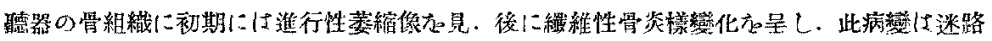

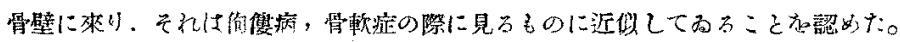

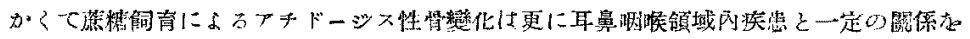
桃すことが知られたのでおる。(白井)

\section{鞭虫虫體乳劑經口的投與の鞭虫感染 及び名虫發育に及ぼす影響}

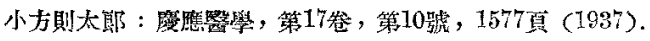

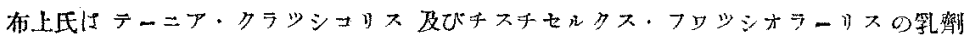

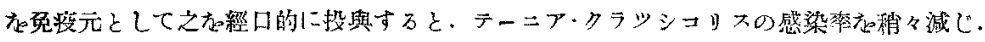

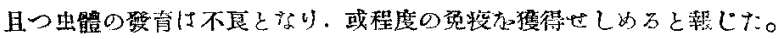

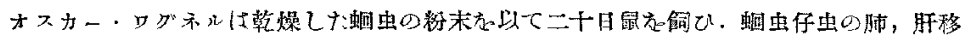

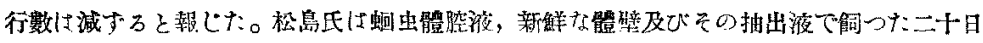

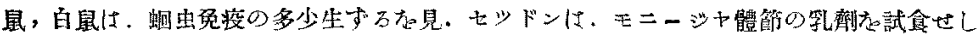

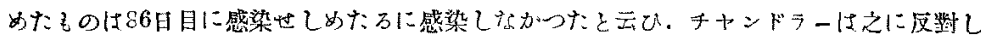
ホ。

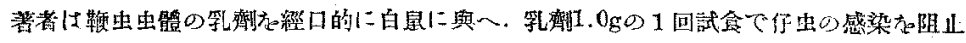

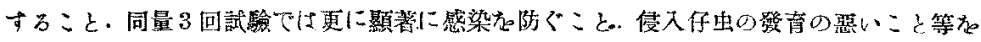

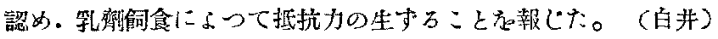

